\title{
H1-6 Gene
}

National Cancer Institute

\section{Source}

National Cancer Institute. H1-6 Gene. NCI Thesaurus. Code C162864.

This gene plays a role in the formation of relaxed chromatin structures. 